SBedergi, 2021; 5(9), 181-203.

DOI: $10.29228 /$ sbe. 51843

E-ISSN: $2602-4306$

www.sbedergi.com

Geliş Tarihi (Received): 21.06.2021

Kabul Tarihi (Accepted): 30.11.2021

\title{
SİBER ZORBALIK DAVRANIŞLARININ YAPAN VE UĞRAYAN AÇISINDAN FARKLI DEĞIŞKENLERE GÖRE İNCELENMESİ
}

\author{
Yıldırım YILDIRIM1 \\ https://orcid.org/ 0000-0002-5851-7788
}

$\ddot{O} \mathbf{z}$

Siber zorbalık bugünün en popüler ve araştırmacıların ilgisini en çok çeken konular arasında yer almaktadır. Gelişen internet ve bilgi teknolojileri ve bu teknolojilere ulaşımın ve sahip olmanın maliyetinin giderek azalması, kişilerin çok daha fazla internette vakit geçirmelerine neden olmaktadır. Siber zorbalık davranışının hem yapan hem de uğrayan açısından değerlendirildiği bu çalışmada ilgili literatür için önemli sonuçlara ulaşılmıştır. 27 Haziran - 27 Eylül 2019 tarihleri arasında 549 kişiden online anket yöntemiyle toplanan veriler neticesinde kişilerin internette ve sosyal medyada geçirdikleri sürenin siber zorbalık gösterme eğilimlerini arttırdığı, siber zorbalığa en çok kadınların uğradı $\breve{g}$, erkeklerinse siber zorbalık göstermede kadınlardan daha önde olduğu bulunmuştur. Ayrıca, siber zorbalık davranışı ile gelir düzeyi arasında anlamlı bir ilişkinin olduğu görülmüştür. Siber zorbalığa uğrayanların daha çok asgari ücret ve altı gelire sahip kişiler olarak ortaya çıkmıştır. En çok 15-24 yaş grubunun zorba davranışlar sergilediği, siber zorbalığa uğrayanlar arasında 45-54 yaş grubunun da olduğu ortaya çıkmıştır. Çalışmanın bir diğer önemli bulgusu ise interneti kullanım amaçları ile siber zorbalığa maruz kalma veya siber zorbalık gösterme arasında pozitif ve anlamlı ilişkilere rastlanmış olmasıdır.

Anahtar kelimeler: Siber Zorbalık, Siber Zorba, Siber Mağdur, Demografik Değişkenler

\section{INVESTIGATION OF CYBERBULLYING BY DIFFERENT VARIABLES IN TERMS OF THOSE WHO MAKE AND EXPOSED}

\begin{abstract}
Cyberbullying is one of the most popular and most interesting topics of today's researchers. The developing internet and information technologies and the decreasing cost of accessing and owning these technologies cause people to spend more time on the internet. In this study, in which cyberbullying behavior is evaluated in terms of both the perpetrator and the victim, important results have been reached for the relevant literature. As a result of the data collected from 549 people between June 27 and August 27, 2019, it was found that the time people spend on the internet and social media increases their tendency to show cyberbullying, that women are the most exposed to cyberbullying, and men are ahead of women in showing cyberbullying. In addition, it has been seen that there is a significant relationship between cyberbullying behavior and income level in this study. It has emerged that the victims of cyberbullying are mostly those

\footnotetext{
1 Doç. Dr., Düzce Üniversitesi Akçakoca Turizm İşletmeciliği ve Otelcilik Yüksekokulu, yildirimyildirim@duzce.edu.tr
} 
with minimum wage and below income. It has been revealed that the 15-24 age group exhibits bullying behaviors most, and the 45-54 age group is also among the victims of cyberbullying. Another important finding of the study is that positive and significant relationships were found between the purposes of using the internet and being exposed to or showing cyberbullying.

Key words: Cyberbullying, Cyber Bully, Cyber Victim, Demographic Variables

\section{GİRIS}

İnternetle birlikte insanların kendilerini ifade biçimleri kolaylaşmış, kendini özgür hisseden birey, başkasının özgürlük alanına girmekten çekinmemiş ve bu da bazı davranış bozukluklarını beraberinde getirmiş̧ir. Kişi, kendi gibi düşünmeyen, kendi gibi konuşmayan ve kendi gibi olmayan bireyleri sanal ortamda dışlama eğilimi göstermiş ve hoşuna gitmeyen her türlü durumu açıkça eleştirmiştir. Eleştiri dozunu hakaret, psikolojik saldırı, küfür, ideolojik baskılama, üstünlük kurma gibi erdem dışı davranışlarla arttıran birey, internet ortamını hınç, öç alma, öfke boşaltımı aracı olarak kullanmışıtır. Siber zorbalık olarak adlandırılan, kişinin psikolojisine ve ruhsal durumuna yönelik yapılan baskılamalar, son günlerin sıkça karşılaşılan durumlarındandır. Üstelik gelir düzeyi, sınıfsal farklılıklar, yaş ve eğitim seviyesi gibi faktörlere aldırış etmeden her türlü insanın her türden siber saldırıyı kolayca yapabildiği siber bir çağa girilmiştir. Alakasız gibi görülen, masum sayılan, gündelik her türlü aktivitenin içine sızan siber zorbalık davranışı, sanal dünyaya adımımızı attı̆ımız andan itibaren bir tehlike unsuru olarak bizleri beklemektedir. YouTube sitesinde çok severek dinlediğimiz bir sanatçının müzik videosu altında yapılan binlerce yorum pek çok türden (cinsel, ideolojik, ruhsal, dini vs.) saldırıyı içinde barındırmaktadır. Veyahut takip edilen ünlü bir kişiye yönelik yorum, diğer kişilerce beğenilmediğinde eleştiri okları yorum yapana yönelebilmektedir. Çocuk oyunları/videoları ve dini sitelerde bile çokça rastlanılan zorba davranışlar kendini en çok "yorum" şeklinde göstermekte ve bu yorumları yapanların kimliği kullandıkları "nick name" olarak bilinen "takma adlar" nedeniyle tespit edilememektedir. Kişiyi kendinden şüphe duyma, güvenini azaltma, insanlardan uzak durma, içine kapanıklık, pişmanlık, yetersizlik gibi yönlerden olumsuz olarak etkileyen siber zorbalık, üzerinde çokça araştırma yapmayı hak eden başlıklar arasındadır. Akademik düzeyde yapılacak daha fazla araştırma siber zorbalığa karşı alınacak önlemleri de beraberinde getirecektir. Bu konuda yasal uygulayıcılara ve ebeveynlere yol haritası çizebilmek ve neyin nasıl önlenebileceği hususunda öneri sunabilmek, yapılacak araştırmaların sayısının 
arttırılmasına bağlıdır. Bu kapsamda bu çalışmanın mevcut literatüre ilave değer ekleyeceği ve siber zorbalık hakkındaki alan yazını genişletecektir.

$\mathrm{Bu}$ çalışmanın temel problemi: siber zorbalık davranışının yalnızca zorbalık gösteren kişiyle mi ilişkili olduğu yoksa zorbalık gösteren kişinin kendisinin de bir gün zorba davranışlara uğrayarak bunun mağduru olabileceğini ortaya koymaktır. Nitekim bugün siber zorbalık mağduru olanların gelecekte zorba olma potansiyelleri olduğu unutulmamalıdır (Kaygısız, 2019; Özer ve Şad, 2021). Siber zorbalık davranışlarını bu bağlamda hem zorbalık gösteren hem de bu zorbalığa maruz kalan kişilerce ele almak ve bu davranışların demografik faktörlere, sosyal medya ve internet kullanımına (süresine, amacına vs.) göre değişip değişmediğini belirlemektir. Günümüzde demografik değişkenler zorbalık gösterme ve zorbalığa uğramanın birer yordayıcısı olarak görülmektedir (Bostan ve diğg., 2020). Literatürde siber zorbalık davranışları daha çok akran grupları arasında, ergenlerde ve lise ile ortaokul eğitim düzeyinde incelenmiştir (Gelmez, 2020; Özer ve Şad, 2021; Bolat ve Korkmaz, 2021; Bilgiz ve Peker, 2020; Karoğlu ve Çılğın, 2020; Dinç, 2020). Bu çalışmaların bulguları farklılık gösterse de zorbalık davranışlarına öğretmenlerin (Alanoğlu ve Karabatak, 2020; Kaygısız ve Çakır, 2020), erkeklerin (Erbiçer, 2019; Dursun vd., 2020), genç ve ergenlerin (Dinç, 2020), internette ve sosyal medyada çok daha fazla zaman geçirenlerin (Efe vd., 2021; Bolat ve Korkmaz, 2021; Özer Öksüzoğlu, 2021; Alanoğlu ve Karabatak, 2020; Türkoğlu, 2013; Çiftçi, 2010; Erdur-Baker ve Kavşut, 2007) siber zorbalık davranışlarına daha çok maruz kaldığı bilinmektedir. Yalnızca gençlerin ve ergenlerin değil toplumun eğitimli kesimi olan öğretmenlerin dahi siber zorbalık mağduru olabildiği bilinmektedir (Kaygısız ve Çakır, 2020). Bu çalışma sonucunda ortaya çıkacak bulgular zorbalık davranışlarını hem demografik faktörler hem de internet ve sosyal medya kullanım süresiyle nasıl ilişkilendirildiğine açıklık getirecek, ileride hükümetin, Millî Eğitim Bakanlığının ve diğer kanun yapıcıların yasal düzenlemelerine teorik katkı sunacaktır.

\section{KAVRAMSAL ÇERÇEVE}

Bilişim ve iletişim teknolojileri günden güne gelişmektedir ve kullanım oranı artmaktadır (Eroğlu ve Peker, 2015: 593). Bu gelişim kişilerin istediği bilgi kaynağına hızlı ve kolay bir şekilde ulaşmasını, aynı anda aynı mekânda bağımsız iletişim kurmasını sağlamaktadır ve sosyal paylaşım siteleri kişilerin sosyalleşmelerine yardımcı olmaktadır. 
Aynı zamanda öğrenme ve öğretme ortamları da sunmaktadır (Akça vd., 2014: 17). Pek çok ülke, okullarda teknoloji kullanımını arttırmak, e-devlet uygulamalarını yaygınlaştırmak ve teknoloji okur-yazarlığını arttırabilmek için girişimlerde bulunulmaktadır (Kaşıkçı vd., 2014: 232). Siber zorbalık kavramı teknolojinin hızlı gelişimi ve bireylerdeki değişikliklerin bir tezahürü olarak ortaya çıkmıştır (Toraman ve Usta, 2018: 59). Siber zorbalık davranışı teriminin siber olan kısmı bilgi ve iletişim tekniklerine atıfta bulunurken, zorbalık terimi ise karşı tarafa zarar verme amaciyla yapılan eylemleri tanımlamaktadır (Korkmaz, 2016: 620).

Siber zorbalık, bilgi iletişim teknolojileri aracılığıyla bireylerin birbirlerine düşmanlık, korkutma, tehdit, sindirme, taciz amaçlı yazılı ve görsel iletileri kasıtlı ve düzenli bir şekilde göndermeleri anlamına gelmektedir (Akça vd., 2014: 18). Artan internet ve cep telefonu kullanımı zaman zaman bireyler arasında siber zorbalık ve kötü davranışların sergilenmesine neden olmaktadır (Çivilidağ ve Cooper, 2013: 497). Eskiye nazaran yaygınlaşan cep telefonları ve sosyal ağlar internetin kötü amaçlı kullanımını kolaylaştırmakta ve akran zorbalığının sanal hali olan siber zorbalık bilişim teknolojilerinin oluşturduğu risklerin başında gelmektedir. (Toraman ve Usta, 2018: 5960). Özellikle ergenler arasında hızla yayılan bu teknolojinin kullanımı beraberinde birçok olumsuzluğu da getirmiştir (Eroğlu ve Peker, 2015: 593). Ergenlik dönemi süresince, gençler arasında ilişkiler önemli hale gelmektedir. Bu ilişkiler sosyal ve psikolojik gelişimlerinde etkili olmaktadır (Aktepe, 2013: 31). Fotoğraf ve video çekmek, bunları elde etmek, paylaşmak, çoğaltmak bugünün şartlarında zor olmamaktadır. Bilhassa yeni neslin teknolojiye olan yatkınlıkları, sosyal ağları ve interneti hem hızlı hem de bazen amacı dışında kullanmaları çekilen bu resimlerin/videoların kontrolsüz şekilde yayılmasına ve zorbalık davranışlarına neden olmaktadır (Korkmaz, 2016: 623). İnternetin hızla yayılması geleneksel zorbalığın internete taşınmasına yol açmaktadır ve siber zorbalık adı verilen bir zorbalık türünün ortaya çıkmasına neden olmaktadır (Aktepe, 2013: 31). Ergenlerin bu tür olaylara en çok uğrayan ve savunmasız olarak adlandırılabilecek gruplardan olması, siber zorbalığın ve mağduriyetin incelenmesini, araştırılmasını, acil önlemlerin alınmasını mecbur kılmaktadır. Çünkü sanal dünyada ergen yaştakileri korumak, onların ruhsal ve fiziki olarak sağlıklı olmalarını sağlamak anlamına gelmektedir (Korkmaz, 2016: 622). Bilinmektedir ki erken yaşların mutlu bir şekilde geçirilmesinin ergenin şimdiki ve gelecekteki yaşamı üzerinde olumlu etkileri 
olabileceği gibi, başarısızlık ve sıkıntıların da olumsuz sonuçlara yol açabileceği unutulmamalıdır. Bu bakımdan ergenin şimdiki zamanını ve geleceğini negatif şekilde etkileyebilecek davranışlardan sayılan siber zorbalıkla ilgili yapılan çalışmaların çocuğun zihinsel gelişimi, psikolojisi ve yaşadığı toplum için son derece önemli olduğu bilinmelidir (Ateş ve Güler, 2016: 401). Eroğlu ve Peker (2015), ergenlerde siber zorbalığı önlemeye yönelik hazırlanan müdahale programlarında akran ilişkilerine odaklanılması gerektiğini ortaya koymaktadır.

Peker (2015) ergenlerin, bilişim ve iletişim teknolojilerini kullanırken gerçek hayattaki gibi davranışlarına yön veren sosyal normların olmamasının sanal ortamda saldırgan davranışlar göstermelerine neden olabileceği sonucuna ulaşmıştır. Teknolojinin gençler arasında hızla yayılmasının nedenlerinden biri de teknolojik araçları ustalıkla kullananların diğer bireylerle alay ederek akranlar arasında saygınlık kazanabilme düşüncesidir. Teknolojinin gelişmesiyle hayranlık duyma konusu da değişmiştir. Geçmişte fiziksel bakımdan güçlü akranlara hayranlık duyulurken şimdi teknolojide ustalaşmış kişilere hayranlık duyulduğu gözlemlenmiştir. Bilişim ve iletişim teknolojilerinde görülen gelişmelerin, akran gruplarında egemen olan değerlerin değişmesine yol açmasının teknolojik yeterliliği yüksek bireyleri ön plana çıkardığı ve gençlerin siber zorbalık yaparak kendilerini kanıtlamaya çalışmasına neden olduğu ileri sürülebilir (Eroğlu, 2011: 27). Birden fazla sosyal ăg hesabına sahip olmak, sohbet odalarında fazla zaman harcamak, kişinin anonim olarak adlandırılan sahte/bilinmeyen hesaplarla iletişime geçme riskini arttırmakta ve bu durum siber zorbalık mağduru olma ihtimalini kuvvetlendirmektedir. İlaveten, öğrencilerin intikam almak amacıyla zorbalık yaptıkları ancak başkalarına zorbalık yapanında günü geldiğinde mağdur olabileceği vurgulanmaktadır (İğdeli, 2018: 71).

Erdur-Baker ve Kavşut (2007) araştırmalarında Türkiye'deki siber zorbalık oranının \%28, sanal mağdur oranının ise \%30'a ulaştığını ifade etmişlerdir. Türkiye İstatistik Kurumu (TÜIKK) 2019 raporunda internet kullanan bireyler \% 75,3 olarak hesaplanmıştır. Bu kullanım oranlarının \%93,9'unun mesajlaşma, \%82,7'sinin internet üzerinden telefon ile görüşme/video görüşmesi, \%81,4'ünün ise sosyal medya üzerinde profil oluşturma, mesaj gönderme veya fotoğraf vb. içerik paylaşma gibi internet kullanımı yapıldığ görülmektedir. Çivilidağ ve Cooper (2013) yaptıkları araştırmada ergenler arasında öfke değişkeninin Anadolu lisesindeki ergenlerin öfke alt boyutlarından öfke içe ve öfke dışa 
alt boyut sıra ortalama puanlarının genel liselerdeki ergenlere göre anlamlı düzeyde daha yüksek olduğu sonucuna ulaşmıştır. Akça vd. (2014) yaptığ 1 Avrupa Çevrimiçi Çocuklar Projesi kapsamında Türkiye'de yapılan araştırmada, çocukların sadece \%40'ının evinde bilgisayar olduğu ve ebeveynlerin bilgisayar kullanma yeterliliğinin çocuklardan daha az olduğu belirlenmiştir. Elde edilen veriler Türkiye'de siber zorbalığı tespit edebilmek için önem taşımaktadır. Ebeveynlerin çocuklanın karşılaşacağı olumsuz durumlar konusunda yardımcı olabilmede yetersiz kalacaklarını göstermektedir. Bu rakamlar Türkiye'de siber zorbalığı anlamak açısından da önem taşımaktadır. Çünkü ebeveynlerin, çocukların internette karşılaşacakları riskler ya da teknolojik sorunlar konusunda çocuklarına yardımcı olmak konusunda yetersiz kalacaklarını savunmaktadır. Akbaba ve Eroğlu (2013)'nun yaptığı araştırma sonucunda ise ilköğretim öğrencilerinin anne ve babalarının eğitim düzeyinin düşmesinin siber zorbalık yapma davranışlarını arttırdığını ortaya koymaktadır. Özdemir'in (2019) yaptığı araştırmaya göre, öğrencilerin cep telefonlarını kullanmaları siber zorbalık davranışlarını arttırmaktadır. Küfretmek en çok tercih edilen siber zorbalık davranış türüdür. Okul yöneticileri tarafından, öğrenciler siber zorbalığın olumsuz sonuçları hakkında uyarılmalıdır. Aydın ve Çelik (2019) ise çalışmasında velilerin gözünden internet ve sosyal medyayı değerlendirmiş ve çalışma sonunda bazı değerli öneriler sunmuşlardır. Örneğin çocuklar sosyal medyayı kullanma konusunda kendilerini sınırlamak istiyorlarsa ailelerinin koydukları kurallara uymaları gerektikleri, kötü içerikli sitelere girmemeleri, gizlilik ve güvenliğe azami ölçüde dikkat etmeleri, yaşananlardan ders almaları gerektiği vurgulanmış, dışarı çıkıp fiziki aktivitelerde bulunmanın, yüz yüze iletişim kurmanın ve aile ile daha çok zaman geçirmenin önemi üzerinde durulmuştur.

\section{2. ÇALIŞMANIN AMACI VE YÖNTEMI}

$\mathrm{Bu}$ çalışmanın temel amacı kişilerin siber zorbalığa uğrama ve siber zorbalık gösterme davranışlarını ortaya koymaktır. Ayrıca, siber zorbalığa uğramanın ve siber zorbalık gösterme davranışının sosyal medya kullanımı ve internet kullanımı ile bir ilişsisi olup olmadığını belirlemek, siber zorbalık durumunun yaş, gelir, cinsiyet gibi değişkenlere göre farklılaşıp farklılaşmadığını öğrenmekte araştırmanın amaçları arasında sayılabilir. Bu amaçlarla, veriler 27 Haziran - 27 Eylül 2019 tarihleri arasında online olarak düzenlenen anket yoluyla 549 kişiden elde edilmiştir. Kullanılan anket formu için Erdur- 
Baker ve Kavşut (2007) ile Arıcak, Kınay ve Tanrıkulu'nun (2012) çalışmalarından yararlanılmıştır. Anketin ilk kısmında cinsiyet, gelir, yaş, meslek, eğitim durumu, medeni durum, çocuk sayısı gibi demografik sorular sorulmuştur. İkinci kısmında ise internette ve sosyal medyada geçirilen süre, interneti kullanım amaçları, siber zorbalığa karşı yasal hakların farkındalığı, nerden yardım alacaklarını bilip bilmedikleri, herhangi bir siber tehdit gösterip göstermedikleri veyahut siber zorbalığa uğrayıp uğramadıkları sorulmuştur. Anketin son bölümünde ise siber zorbalığa uğrama ve siber zorbalık gösterme durumları verilmiş olup, cevaplayıcılardan bu durumlarla ne ölçüde karşılaştıkları ve bu durumları kendilerinin ne ölçüde karşı tarafa uyguladığı sorulmuştur.

Siber zorbalık dijital gelişmelerin olumsuz bir getirisi olarak kabul edilmektedir. Elektronik ortamda gerçekleştirilen zorbalık davranışları birden fazla faktöre bağlı olarak gerçekleşmektedir (Bilgiz ve Peker, 2020). Yaş faktörü siber zorbalık literatüründe fail ya da mağdur olma durumunu etkileyen faktörlerden biridir. Her ne kadar bu konuda farklı bulgular ortaya çıksa da yaşın siber zorbalığa karşı koruyucu bir faktör olduğu belirtilmektedir (Forsell, 2018). Bazı çalışmalar yaşı genç olan kişilerin siber zorbalık gösterdiği konusunda uzlaşırken, bazı çalışmaların sonuçları orta yaş ve yaşlıların da zorba olabileceğini göstermektedir. Yaş ile siber zorbalık konusundaki bağlantı internet kullanma becerisi ve sosyal medyada geçirilen süre sayesinde kurulabilmektedir. Dijital araçları kullanan kesimin daha çok gençlerden oluşması onları hem siber zorba mağduru hem de siber zorbalığın faili yapmaktadır. Siber zorbalık konusunda yapılan çalışmaların cinsiyetle olan sonuçlarına bakıldığında aynı çelişkinin bu değişken içinde varolduğunu görmekteyiz. Bazı çalışmalar kadınların erkeklere göre çok daha fazla siber zorbalığa uğradığını, erkeklerin ise zorbalık göstermede çok daha önde olduğunu söylerken (Peker vd., 2012; Karaca, 2019; Bolat ve Korkmaz, 2021; Öksüzoğlu, 2021); bazı çalışmalar ise erkeklerin siber zorbalık kurbanı olduğunu belirtmektedir (Forsell, 2016). Hem cinsiyet hem de yaş konusunda literatürde varolan bu çelişkili bulgular bu konu hakkında daha fazla araştırma yapmayı gerektirmektedir. Bir alanda kuram oluşturabilmek ve genel geçer bir kabul alabilmek ancak çok sayıda çalışmanın tutarlı sonuçlarıyla mümkündür. Siber zorbalığın uğrayan ve yapan açısından demografik faktörlerle ilişkisine bakılması bu alana katkı sağlayacak ve daha sağlam temellerin oluşmasını mümkün kılacaktır.

Araştırmanın amaçları doğrultusunda geniş çaplı literatür taraması sonucunda aşağıdaki hipotezler geliştirilmiştir. 
$\mathrm{H}_{1}$ : Siber zorbalık gösterme ve siber zorbalığa uğrama durumu ile demografik faktörler arasında anlamlı bir ilişski vardır

$\mathrm{H}_{1 \mathrm{a}}$ : Siber zorbalık gösterme ve siber zorbalığa uğrama durumu ile yaş arasında anlamlı bir ilişki vardır.

$\mathrm{H}_{1 b}$ : Siber zorbalık gösterme ve siber zorbalığa uğrama durumu cinsiyete göre farklılaşmaktadır

$\mathrm{H}_{1 \mathrm{c}}$ : Siber zorbalık gösterme ve siber zorbalığa uğrama durumu gelire göre farklılaşmaktadır

Dijital araçların gelişmesi, özellikle sosyal medyanın sahip olduğu etkileşim özelliği kişilerin birbirleri hakkında düşündüklerini kolayca karşı tarafa söyleyebilmelerine imkân tanımıştır (Dursun vd., 2020). Sosyal medyanın gizli hesaplar oluşturma, takma ad kullanma, sahte hesaplar açma konusunda sağladığı üstünlükler yine siber zorbalık davranışlarını arttıran unsurlar olarak düşünülebilir. Kimliğini gizlemek ve sanal alemde anonim bir profil sergilemek, kişinin davranışlarında daha özgür ve ölçüsüz olabilmesine neden olmaktadır (Field, 2018). İnternette daha çok vakit geçiren (Bellici ve Yalçınkaya), birden fazla sosyal medya hesabı olan, sosyal medyada aktif olarak yer alan (yorum yapan, beğenen, resim/video paylaşan vs.) kişilerin (Dinç, 2020) diğer kişilere göre daha fazla siber zorbalığa maruz kaldığı bilinmektedir (Chang vd., 2014; Efe vd., 2021). Bu kişilerin ergenlerden, yaşı genç olanlardan ve internet ile bilgi iletişim teknolojilerini daha iyi, ustalıkla kullanabilen (Özateş Gelmez, 2020; Bostan vd., 2020) kişilerden oluşması yine alan yazında sıkça ortaya çıkan sonuçlardan biridir. İnternette geçirilen süre arttıkça bireylerde hem internet bağımlılığının ortaya çıktığı (Bolat ve Korkmaz, 2021) hem de siber zorbalık davranışlarını arttırdığı bilinmektedir. Bu anlamda bilgisayar, cep telefonu ve internet kullanımının artması hem zorbalık hem de mağduriyetleri arttırmaktadır (Karoğlu ve Çılğın, 2020; Dursun vd., 2020).

Yukarıda teorik temeller 1şığında yapılan açıklamalar doğrultusunda aşağıdaki hipotezler geliştirilmiştir.

$\mathrm{H}_{2}$ : Siber zorbalık gösterme veya siber zorbalığa uğrama durumu ile internette geçirilen süre arasında anlamlı bir ilişkisi vardır (İnternette daha çok vakit geçiren daha çok veya daha az mı siber zorbalığa uğramakta/siber zorbalık göstermektedir) 
$\mathrm{H}_{3}$ : Siber zorbalık gösterme veya siber zorbalığa uğrama durumu ile sosyal medyada geçirilen süre arasında anlamlı bir ilişkisi vardır (Sosyal medyada daha çok vakit geçiren daha çok veya daha az mı siber zorbalığa uğramakta/siber zorbalık göstermektedir)

\section{ARASTTIRMANIN BULGULARI}

$\mathrm{Bu}$ bölümde araştırmanın amaçları ve geliştirilen hipotezler çerçevesinde bazı analizler gerçekleştirilmiştir. Frekans analizleri, ANOVA ve t-Testleri ile değişkenler arasındaki ilişki ve farklılıklara bakılmıştır. Çalışmanın sonunda ise hipotezlerin kabul ve ret durumları özet bir tablo ile okuyuculara sunulmuştur. Tablo 1'de demografik değişkenlere ait betimleyici istatistiklere yer verilmiştir.

Tablo-1: Demografik Değişkenlere Yönelik Frekans Tablosu

\begin{tabular}{|c|c|c|c|}
\hline Demografik Değişkenler & Gruplar & Frekans (n) & Yüzde (\%) \\
\hline \multirow{3}{*}{ Cinsiyet } & Erkek & 232 & 42,3 \\
\hline & Kadın & 317 & 57,7 \\
\hline & Toplam & 549 & 100 \\
\hline \multirow{4}{*}{ Medeni Durum } & Evli & 241 & 43,9 \\
\hline & Bekâr & 287 & 52,3 \\
\hline & Boşanmış/eşi Ölen & 21 & 3,8 \\
\hline & Toplam & 549 & 100 \\
\hline \multirow{3}{*}{ Eğitim Düzeyi } & Lise düzeyi ve altı & 106 & 19,3 \\
\hline & Lise düzeyi üstü & 443 & 80,7 \\
\hline & Toplam & 549 & 100 \\
\hline \multirow{3}{*}{ Çocuk sayısı } & 2 çocuk ve altı & 533 & 97,1 \\
\hline & 3 çocuk ve üzeri & 16 & 2,9 \\
\hline & Toplam & 549 & 100 \\
\hline \multirow{4}{*}{ Yaş } & 24 yaş ve alt1 & 184 & 1,8 \\
\hline & $25-34$ yaş & 240 & 31,7 \\
\hline & 35 yaş ve üstü & 125 & 0,9 \\
\hline & Toplam & 549 & 100 \\
\hline \multirow{3}{*}{ Hane Halk1 Geliri } & Asgari ücret ve altı & 211 & 38,4 \\
\hline & Asgari ücret üstü & 338 & 61,6 \\
\hline & Toplam & 549 & 100 \\
\hline \multirow{5}{*}{ Mesleğiniz } & Özel sektör & 109 & 19,9 \\
\hline & Kamu sektörü & 198 & 36,1 \\
\hline & Kendi işim & 24 & 4,4 \\
\hline & Diğer & 218 & 39,7 \\
\hline & Toplam & 549 & 100 \\
\hline
\end{tabular}

Araştırmaya katılanların cinsiyet dağılımına bakıldığında \%42,3'ünün erkek, \%57,7'sinin kadın olduğu görülmektedir. Medeni durum açısından, \%43,9'unun evli, \%52,3'ünün bekâr, \%3,8'inin ise dul/eşi ölmüş olduğu görülmektedir. Katılımcıların 
büyük çoğunluğu lise düzeyi üzeri eğitim seviyesine sahiptir. Burada araştırmacı araştırma sonrası ortaya çıkan gözlenen değerler arasında büyük farklılıklar olduğundan eğitim seviyesi gruplarını birleştirmiş ve ikili bir sınıflandırmaya tabi tutmuştur. Çocuk sayısı bakımından katılımcıların neredeyse tamamının $(\% 97,1)$ en fazla iki çocuğu olduğu, gelir bakımından ise \%61,6'sının asgari ücret üstü gelire sahip olduğu görülmüştür. Yaş dağılımına bakıldığında \%43,7 ile 25-34 yaş arası en büyük yüzdeyi oluştururken, \%31,7 ile 15-24 yaş arası ikinci sırada, \%17,3 ile 35-44 yaş arası kişiler üçüncü ve \%4,6 ile 45-54 yaş arası kişiler son sırada en az yüzdeye sahip grubu oluşturmaktadır. Meslek bakımından değerlendirildiğinde katılımcıların \%39,7'sinin diğer seçeneği işaretlediği, yani öğrenci, işsiz, ev hanımı, emekli gibi cevaplar verdiği görülmüştür. Diğer seçeneğini, kamu sektörü takip etmekte $(\% 36,1)$, sonra da özel sektör \%19,9 ile üçüncü sırada gelmektedir. En az orana ise kendi işimin patronuyum cevabını verenler sahiptir $(\% 4,4)$.

Tablo-2: Diğer Değişkenlere Yönelik Frekans Analizi

\begin{tabular}{|c|c|c|c|}
\hline Diğer Değişkenler & Gruplar & Frekans (n) & Yüzde $(\%)$ \\
\hline \multirow{6}{*}{$\begin{array}{c}\text { Günde kaç saatinizi internette } \\
\text { geçirirsiniz? }\end{array}$} & Hiç & 5 & 0,9 \\
\hline & $1-3$ & 299 & 54,5 \\
\hline & $4-6$ & 175 & 31,9 \\
\hline & $7-9$ & 44 & 8,0 \\
\hline & 10 saat ve üzeri & 26 & 4,7 \\
\hline & Toplam & 549 & 100 \\
\hline \multirow{5}{*}{$\begin{array}{c}\text { Günde kaç saatinizi sosyal medyada } \\
\text { geçirirsiniz? }\end{array}$} & $1-3$ & 410 & 74,7 \\
\hline & $4-6$ & 98 & 17,9 \\
\hline & $7-9$ & 25 & 4,6 \\
\hline & 10 saat ve üzeri & 16 & 2,9 \\
\hline & Toplam & 549 & 100 \\
\hline \multirow{3}{*}{$\begin{array}{l}\text { Herhangi bir siber tehditle karşılaştınız } \\
\qquad \mathrm{mı} \text { ? }\end{array}$} & Evet & 130 & 23,7 \\
\hline & Hayır & 419 & 76,3 \\
\hline & Toplam & 549 & 100 \\
\hline \multirow{3}{*}{$\begin{array}{l}\text { Herhangi bir siber tehdit gösterdiniz } \\
\text { mi? }\end{array}$} & Evet & 14 & 2,6 \\
\hline & Hayır & 535 & 97,4 \\
\hline & Toplam & 549 & 100 \\
\hline \multirow{3}{*}{ Haklarınızı biliyor musunuz? } & Evet & 203 & 37,0 \\
\hline & Hayır & 346 & 63,0 \\
\hline & Toplam & 549 & 100 \\
\hline \multirow{3}{*}{$\begin{array}{c}\text { Nereden yardım alacağınızı biliyor } \\
\text { musunuz? }\end{array}$} & Evet & 200 & 36,4 \\
\hline & Hayır & 349 & 63,6 \\
\hline & Toplam & 549 & 100 \\
\hline
\end{tabular}


Yukarıdaki tablo incelendiğinde araştırmaya katılanların yarısından fazlasının $(\% 54,5)$ internette 1-3 saat arası vakit geçirdiği görülmektedir. Hemen arkasından ikinci sırada \%31,9 oranıyla 4-6 saat, üçüncü sırada \%8 ile 7-9 saat internette vakit geçirme gelmektedir. Sosyal medyada günde kaç saat vakit geçirirsiniz sorusuna ise katılımcıların $\% 74,7$ 'si 1-3 saat, \%17,9'u 4-6 saat, \%4,6's1 7-9 saat ve \%2,9'u ise 10 saat üzeri vakit geçirdiklerini belirtmiştir. Herhangi bir siber tehdit gösterdiniz mi sorusu ile herhangi bir siber tehditle karşılaştınız mı sorularına büyük oranda katılımcılar "hayır" cevabını verseler de bir nokta dikkati çekmektedir. Siber zorbalık gösterdiniz mi sorusuna katılımcılar \%97,4 ile hayır cevabını verirken, siber zorbalıkla karşılaştınız mı sorusuna \% 76,3 ile hayır demişlerdir. Yani bu sonuçtan, siber zorbalığa uğrama durumunun siber zorbalık gösterme durumundan daha fazla olduğu anlaş1lmaktadır. Araştırmaya katılanların büyük çoğunluğu "haklarını” ve “nereden yardım alacaklarını” bilmediklerini söylemişlerdir.

Tablo-3: Katılımcıların İnterneti Kullanma Nedenleri

\begin{tabular}{|l|c|c|c|c|c|}
\hline \multirow{2}{*}{$\begin{array}{c}\text { İnterneti kullanma nedenleri } \\
\text { Güncel gündem haberlerini takip etmek }\end{array}$} & Çok az & $\mathbf{A z}$ & Fazla & $\begin{array}{c}\text { Çok } \\
\text { fazla }\end{array}$ \\
\cline { 2 - 6 } & $\mathbf{\%}$ & $\mathbf{\%}$ & $\mathbf{\%}$ & $\mathbf{\%}$ & $\mathbf{\%}$ \\
\hline Film veya video izlemek & 4,7 & $\mathbf{3 8 , 1}$ & 19,7 & 15,3 & 22,2 \\
\hline Oyun oynamak & 6,2 & $\mathbf{3 8 , 8}$ & 18,0 & 17,9 & 19,1 \\
\hline Müzik dinlemek & $\mathbf{4 3 , 0}$ & 32,2 & 10,7 & 5,8 & 8,3 \\
\hline Ders çalışmak/ödev yapmak & 9,5 & $\mathbf{4 1 , 9}$ & 17,7 & 13,7 & 17,2 \\
\hline Sosyal medyada dolaşmak & 24,0 & $\mathbf{3 6 , 7}$ & 13,8 & 13,3 & 12,2 \\
\hline Magazin takip etmek & 7,5 & $\mathbf{4 0 , 8}$ & 17,3 & 14,6 & 19,8 \\
\hline
\end{tabular}

Katılımcılara interneti genellikle hangi amaçlarla kullandıkları ve bu kullanım sıklıkları sorulmuştur. Sonuçlara göre oyun oynamak ve magazin takip etmek amaçlı interneti hiç kullanmadıklarını, güncel gündem haberlerini takip etmek, film veya video izlemek, müzik dinlemek, ders çalışmak/ödev hazırlamak ve sosyal medyada dolaşmak içinse çok az kullandıklarını belirtmişlerdir. Sütun bazında değerlendirildiğinde katılımcıların interneti güncel gündem haberlerini takip etmek, müzik dinlemek film/video izlemek ve sosyal medyada dolaşmak amaçlı kullandığı görülmektedir. 
Tablo-4: Siber Zorbalık Durumunun Yaş Gruplarına Göre Farkını Belirlemeye Yönelik ANOVA Analizi

\begin{tabular}{|c|c|c|c|c|c|c|c|}
\hline & Grup & $\mathbf{N}$ & Ort & Ss & $\mathbf{F}$ & $\mathbf{p}$ & Fark \\
\hline \multirow{3}{*}{ Siber Zorbalık Yapan } & 24 yaş ve altı & 184 & 1,179 & ,467 & \multirow{3}{*}{14,053} & \multirow{3}{*}{0,000} & \multirow{3}{*}{$\begin{array}{l}1>2 \\
1>3\end{array}$} \\
\hline & $25-34$ yaş & 240 & 1,048 & , 179 & & & \\
\hline & 35 yaş ve üzeri & 125 & 1,020 & 073 & & & \\
\hline \multirow{3}{*}{ Siber Zorbalığa Uğrayan } & 24 yaş ve altı & 184 & 1,430 & 620 & \multirow{3}{*}{14,154} & \multirow{3}{*}{0,000} & \multirow{3}{*}{$\begin{array}{l}1>2 \\
1>3\end{array}$} \\
\hline & $25-34$ yaş & 240 & 1,253 &, 442 & & & \\
\hline & 35 yaş ve üzeri & 125 & 1,145 & ,270 & & & \\
\hline
\end{tabular}

Siber zorbalığa uğrayan ile siber zorbalık yapan kişilerin yaşa göre farkını belirlemek için yapılan ANOVA analizine göre hem siber zorbalık yapan hem de siber zorbalığa uğrayan yaş grubunun 24 yaş ve altı kişiler olduğu ortaya çıkmıştır. Bu yaş grubundaki kişilerin siber zorbalık yapma ve siber zorbalığa uğrama ortalamaları diğer yaş gruplarından (2534 ile 35+ kişilerden) daha yüksektir. 35 yaş ve üzeri olan kişilerin zorbalık yapma ve zorbalığa uğrama durumunun daha az olduğu araştırma sonucunda görülmüştür. Bu da daha ileri yaşlardaki kişilerin siber zorbalık konusunda daha az mağduriyet yaşadığını ve bu tarz uygunsuz davranışları daha az sergilediğini göstermektedir.

Tablo-5: Siber Zorbalık Durumunun Cinsiyete Göre Farkını Belirlemeye Yönelik t-Testi

\begin{tabular}{|c|c|c|c|c|c|c|c|}
\hline Özellik & Grup & $\mathbf{N}$ & Ort & SS & $\mathbf{t}$ & $\mathbf{p}$ & Fark \\
\hline \multirow{2}{*}{ Siber zorbalığa uğrayan } & Erkek & 232 & 1,325 & 0,503 & \multirow{2}{*}{$-1,507$} & \multirow{2}{*}{0,132} & \multirow{2}{*}{ Fark yok } \\
\hline & Kadın & 317 & 1,261 & 0,483 & & & \\
\hline \multirow{2}{*}{ Siber zorbalık yapan } & Erkek & 232 & 1,132 & 1,132 & \multirow{2}{*}{$-2,869$} & \multirow{2}{*}{0,004} & \multirow{2}{*}{ Erkek $>$ Kadın } \\
\hline & Kadın & 317 & 1,051 & 1,051 & & & \\
\hline
\end{tabular}

Siber zorbalığa uğrayan ile siber zorbalık yapan kişilerin cinsiyete göre farkını belirlemek için yapılan t-Testi sonucunda siber zorbalığa uğrayanların cinsiyet açısından farklılık göstermediği yani her iki cinsiyetinde günümüzde siber zorbalığa uğrayabildiği sonucu çıkmıştır. Ancak siber zorbalık gösterme bakımından cinsiyetler arası farka bakıldığında erkeklerin ortalaması kadınlara göre daha yüksek çıkmıştır. Bu sonuç erkek katılımcıların kadın katılımcılardan çok çok daha fazla siber zorbalık yaptıklarını göstermektedir.

Tablo-6: Siber Zorbalık Durumunun Gelir Seviyesine Göre Farkını Belirlemeye Yönelik tTesti 


\begin{tabular}{|c|c|c|c|c|c|c|c|}
\hline Özellik & Grup & $\mathbf{N}$ & Ort & SS & $\mathbf{t}$ & $\mathbf{p}$ & Fark \\
\hline \multirow{2}{*}{ Siber zorbalığa uğrayan } & $\begin{array}{l}\text { Asgari ücret ve } \\
\text { alt1 }\end{array}$ & 211 & 1,371 & 0,571 & \multirow{2}{*}{2,968} & \multirow{2}{*}{$\mathbf{0 , 0 0 3}$} & \multirow{2}{*}{$1>2$} \\
\hline & $\begin{array}{l}\text { Asgari ücret } \\
\text { üstü }\end{array}$ & 338 & 1,236 & 0,429 & & & \\
\hline \multirow{2}{*}{ Siber zorbalık yapan } & $\begin{array}{c}\text { Asgari ücret ve } \\
\text { alt1 }\end{array}$ & 211 & 1,120 & 0,367 & \multirow{2}{*}{1,927} & \multirow{2}{*}{0,055} & \multirow{2}{*}{ Fark yok } \\
\hline & $\begin{array}{c}\text { Asgari ücret } \\
\text { iistii }\end{array}$ & 338 & 1,064 & 0,255 & & & \\
\hline
\end{tabular}

Siber zorbalığa uğrayan ve siber zorbalık yapan kişilerin gelir seviyelerine göre anlamlı farklılık gösterip göstermediklerini belirlemek amacıyla yapılan t-Testi sonucunda asgari ücret ve altı gelire sahip olanların hem siber zorbalığa uğradıkları hem de siber zorbalık gösterdikleri sonucuna ulaşılmıştır. Asgari ücret ve altı gelire sahip kişilerin siber zorbalık gösterme ve siber zorbalığa uğrama ortalamaları diğer gelir grubundan daha fazladır.

Tablo-7: Siber Zorbalık Durumunun İnternette Vakit Geçirme Süresine Göre Farkını Belirlemeye Yönelik ANOVA Analizi

\begin{tabular}{|c|c|c|c|c|c|c|c|}
\hline & Grup & $\mathbf{N}$ & Ort & Ss & $\mathbf{F}$ & $\mathbf{p}$ & Fark \\
\hline \multirow{3}{*}{ Siber Zorbalık Yapan } & 1-3 saat & 304 & 1,038 &, 153 & \multirow{3}{*}{14,572} & \multirow{3}{*}{$\mathbf{0 , 0 0 0}$} & \multirow{3}{*}{$\begin{array}{l}3>1 \\
3>2\end{array}$} \\
\hline & 4-6 saat & 175 & 1,103 & ,307 & & & \\
\hline & 7 saat ve üzeri & 70 & 1,247 & ,596 & & & \\
\hline \multirow{3}{*}{ Siber Zorbalığa Uğrayan } & 1-3 saat & 304 & 1,217 & ,373 & \multirow{3}{*}{8,064} & \multirow{3}{*}{0,001} & \multirow{3}{*}{$\begin{array}{l}2>1 \\
3>1\end{array}$} \\
\hline & 4-6 saat & 175 & 1,348 & ,551 & & & \\
\hline & 7 saat ve üzeri & 70 & 1,442 & ,702 & & & \\
\hline
\end{tabular}

Siber zorbalık yapma ve siber zorbalığa maruz kalma durumlarının internette geçirilen süreye göre bir farklılık oluşturup oluşturmadığı incelendiğinde 4-6 saat arası ile 7 saat ve üzeri internette vakit geçiren kişilerin siber zorbalık yapma ortalamalarının daha fazla olduğu görülmektedir. Buna göre günde 7 saat ve daha fazla internette vakit geçirildiğinde kişilerin siber zorbalık gösterme eğilimlerinin arttığ 1 ve internette harcanan daha fazla sürenin kişileri zorba davranışlara sevk ettiği anlaşılmaktadır. Benzer şekilde 4-6 saat ile 7 saat ve üzeri internette vakit geçirenlerin siber zorbalığa daha fazla uğradıkları anlaşı1mıştır. Burada dikkati çeken önemli husus, siber zorbalık yapmak için daha fazla internette vakit geçirmek gerekirken, siber zorbalığa uğramak için bu vaktin daha kısa olmasıdır. Yani 4-6 saat internette vakit geçirenlerinde siber zorbalığa maruz kaldıkları görülmektedir. Kısacası, siber zorbalığa uğramak, siber zorbalık yapmak kadar internette uzun saatler harcamayı gerektirmemektedir. 
Tablo-8: Siber Zorbalık Durumunun Sosyal Medyada Vakit Geçirme Süresine Göre Farkını Belirlemeye Yönelik ANOVA Analizi

\begin{tabular}{|c|c|c|c|c|c|c|c|}
\hline & Grup & $\mathbf{N}$ & Ort & Ss & $\mathbf{F}$ & $\mathbf{p}$ & Fark \\
\hline \multirow{4}{*}{ Siber Zorbalık Yapan } & $1-3$ saat & 410 & 1,074 & ,254 & \multirow{4}{*}{7,285} & \multirow{4}{*}{0,000} & \multirow{4}{*}{$\begin{array}{l}3>1 \\
3>2 \\
4>1 \\
4>2\end{array}$} \\
\hline & 4-6 saat & 98 & 1,047 &, 150 & & & \\
\hline & $7-9$ saat & 25 & 1,284 & ,695 & & & \\
\hline & 10 saat ve üzeri & 16 & 1,305 & ,751 & & & \\
\hline \multirow{4}{*}{ Siber Zorbalığa Uğrayan } & 1-3 saat & 410 & 1,257 & ,453 & \multirow{4}{*}{4,958} & \multirow{4}{*}{0,002} & \multirow{4}{*}{$\begin{array}{l}4>1 \\
4>2\end{array}$} \\
\hline & 4-6 saat & 98 & 1,312 & ,482 & & & \\
\hline & 7-9 saat & 25 & 1,435 & ,610 & & & \\
\hline & 10 saat ve üzeri & 16 & 1,687 & ,964 & & & \\
\hline
\end{tabular}

Siber zorbalık yapma ve siber zorbalığa uğrama durumlarının sosyal medyada geçirilen süreye göre farklılık oluşturup oluşturmadığını öğrenmek amacıyla yapılan ANOVA analizi sonucunda siber zorbalığa uğrama veya siber zorbalık yapma durumunun sosyal medyada geçirilen süreye göre değiştiği görülmüştür. Buna göre 7-9 saat ile 10 saat ve üzeri sosyal medyada vakit harcayan kişilerin 1-3 saat ile 4-6 saat sosyal medyada vakit geçirenlere göre daha fazla siber zorbalık yapma eğilimi gösterdiği, buna karşın sadece 10 saat ve üzeri sosyal medyada vakit geçiren kişilerin 1-3 saat ile 4-6 saat sosyal medyada vakit geçirenlere göre siber zorbalığa uğrama ortalamasının daha yüksek olduğu görülmüştür. Buradaki sonuç internette vakit geçirme durumundan biraz farkl1lık göstermektedir. Sosyal medyada siber zorbalık yapmak için 7 saat ve üzeri sosyal medyada vakit harcamak yeterliyken, siber zorbalığa uğramak için sadece 10 saat ve üzeri vakit harcamak gerekmektedir. Bu sonuç internette vakit geçirme ile farklılaşmaktadır. İnternette daha kısa sürelerde vakit geçirenlerinde (4-6 saat arası) siber zorbalığa uğradığı görülmüştü. Buna göre zorbalık davranışlarının yalnızca sosyal medyada değil internet ortamının genelinde görülebildiği sonucu çıkabilir. Herhangi bir web sitesinde, bir WhatsApp yazışmasında veya bir işletmenin müşteri temsilcisi ile internet ortamında görüşme sırasında kişi siber saldırıya uğrayabilmektedir. 
Tablo-9: Siber Zorbalık Yapma ve Siber Zorbalığa Uğrama ile İnterneti Kullanım Nedenleri Arasındaki İlişkiye Dair Korelasyon Analizi

\begin{tabular}{|c|c|c|c|c|c|c|c|c|c|c|}
\hline & & 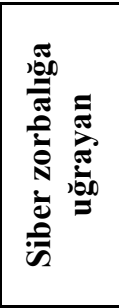 & 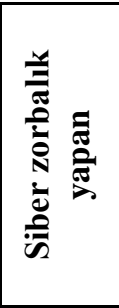 & 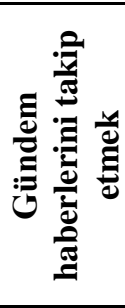 & 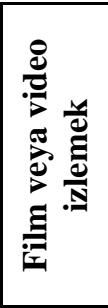 & 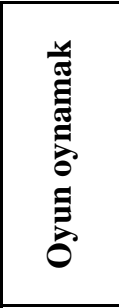 & 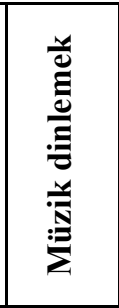 & 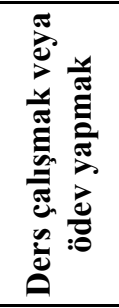 & 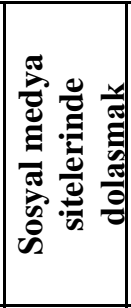 & 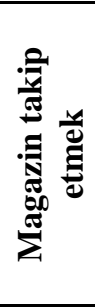 \\
\hline \multirow{2}{*}{$\begin{array}{c}\text { Siber zorbalığa } \\
\text { uğrayan }\end{array}$} & $\mathrm{r}$ & 1,00 & & & & & & & & \\
\hline & $\mathrm{p}$ & 0,00 & & & & & & & & \\
\hline \multirow{2}{*}{$\begin{array}{c}\text { Siber zorbalık } \\
\text { yapan }\end{array}$} & $\mathrm{r}$ & $0,54 * *$ & 1,00 & & & & & & & \\
\hline & $\mathrm{p}$ & 0,00 & 0,00 & & & & & & & \\
\hline \multirow{2}{*}{$\begin{array}{c}\text { Gündem } \\
\text { haberlerini takip } \\
\text { etmek }\end{array}$} & $\mathrm{r}$ & $0,08 *$ & 0,54 & 1,00 & & & & & & \\
\hline & $\mathrm{p}$ & 0,48 & 0,20 & 0,00 & & & & & & \\
\hline \multirow{2}{*}{$\begin{array}{c}\text { Film veya video } \\
\text { izlemek }\end{array}$} & $\mathrm{r}$ & $0,27 * *$ & $0,12 * *$ & $0,49 * *$ & 1,00 & & & & & \\
\hline & $\mathrm{p}$ & 0,00 & 0,003 & 0,00 & 0,00 & & & & & \\
\hline \multirow{2}{*}{ Oyun oynamak } & $\mathrm{r}$ & $0,31 * *$ & $0,31 * *$ & $0,16 * *$ & $0,41 * *$ & 1,00 & & & & \\
\hline & $\mathrm{p}$ & 0,00 & 0,00 & 0,00 & 0,00 & 0,00 & & & & \\
\hline \multirow{2}{*}{ Müzik dinlemek } & $\mathrm{r}$ & $0,30 * *$ & $0,14 * *$ & $0,40 * *$ & $0,64 * *$ & $0,41 * *$ & 1,00 & & & \\
\hline & $\mathrm{p}$ & 0,00 & 0,001 & 0,00 & 0,00 & 0,00 & 0,00 & & & \\
\hline \multirow{2}{*}{$\begin{array}{c}\text { Ders çalışmak/ödev } \\
\text { yapmak }\end{array}$} & $\mathrm{r}$ & $0,24 * *$ & $0,09 *$ & $0,47 * *$ & $0,44 * *$ & $0,14 * *$ & $0,49 * *$ & 1,00 & & \\
\hline & $\mathrm{p}$ & 0,00 & 0,03 & 0,00 & 0,00 & 0,001 & 0,00 & 0,00 & & \\
\hline \multirow{2}{*}{$\begin{array}{c}\text { Sosyal medya } \\
\text { sitelerinde } \\
\text { dolaşmak }\end{array}$} & $\mathrm{r}$ & $0,22 * *$ & $0,09 *$ & $0,36 * *$ & $0,53 * *$ & $0,34 * *$ & $0,49 * *$ & $0,36 * *$ & 1,00 & \\
\hline & $\mathrm{p}$ & 0,00 & 0,03 & 0,00 & 0,00 & 0,00 & 0,00 & 0,00 & 0,00 & \\
\hline \multirow{2}{*}{$\begin{array}{c}\text { Magazin takip } \\
\text { etmek }\end{array}$} & $\mathrm{r}$ & $0,19 * *$ & $0,11^{* *}$ & $0,22 * *$ & $0,38^{* *}$ & $0,27 * *$ & 0,37 & $0,22 * *$ & $0,54 * *$ & 1,00 \\
\hline & $\mathrm{p}$ & 0,00 & 0,008 & 0,00 & 0,00 & 0,00 & 0,00 & 0,00 & 0,00 & 0,00 \\
\hline
\end{tabular}

Tablo 9'a göre siber zorbalık yapma ile siber zorbalığa uğrama arasında orta düzeyde pozitif ve anlamlı bir ilişki bulunmaktadır. Buna göre siber zorbalık gösterenlerin aynı zamanda siber zorbalığa uğradıkları da söylenebilir. Siber zorbalığa en az uğrayanların interneti gündem haberlerini takip etmek ve ders çalışmak/ödev hazırlamak amaçlı kullananlar olduğu görülmüştür. Siber zorbalığa uğrama ile gündem güncel haberleri takip etmek, ders çalışmak, sosyal medya sitelerinde dolaşmak ve magazin takip etmek amaçları arasında çok zayıf ve pozitif korelasyon bulunurken, film/video izlemek, oyun oynamak ve müzik dinleme amaçları arasında zayıf fakat pozitif yönlü bir korelasyon olduğu görülmüştür. Siber zorbalık yapma ile gündem güncel haberlerini takip etme amacı arasında orta düzeyde pozitif, oyun oynamak amacı arasında ise zayıf ve pozitif yönlü korelasyon olduğu görülmüştür. Siber zorbalık yapma ile film/video izlemek, müzik dinlemek, ders çalışmak, sosyal medyada dolaşmak ve magazin takip etmek amaçları arasında ise çok zayıf ve pozitif bir ilişki ortaya çıkmıştır. 


\section{SONUÇ VE ÖNERİLER}

Siber zorbalık davranışlarının yapan ve uğrayan açısından incelendiği bu çalışmada, veriler 549 kişiden çevrim içi anket yoluyla toplanarak gerçekleştirilmiştir. Siber zorbalık göstermek kadar siber zorbalığa uğramanın da son derece yıkıcı etkileri olduğu söylenebilir. Kişiyi ve yaşamını doğrudan etkileyen, psikolojik ve ruhsal yapısını bozan bu tür davranışların, özellikle internet erişiminin ve kullanımının ucuzlaşması ve yaygınlaşması neticesinde daha da arttığı gözlemlenmiştir. Siber zorbalık davranışlarını hem yapan hem de bu davranışlara maruz kalan kişilerin, temel nedenlerini ortaya koymak, siber zorbalık davranışlarının çeşitli demografik faktörler ile internet ve sosyal medya kullanımına göre değişip değişmediğini incelemek amacıyla yapılan bu çalışmada aşağıdaki sonuçlara ulaşılmış ve bu sonuçlar literatürdeki diğer sonuçlar ile karşılaştırmalı olarak tartışılmıştır. Elde edilen sonuçlar doğrultusunda yasal uygulayıcılara ve ebeveynlere çeşitli öneriler sunulmaktadır.

Günlük 7 saat ve üzeri internette vakit geçirenlerin oranı \%12,7'dir. Bu oran sosyal medyada \%7,5'dir. Bu sonuçlar dikkate alındığında kişilerin genel itibariyle sosyal medyada daha az fakat internette daha fazla vakit geçirdikleri görülmektedir. İnternetin sosyal medyadan oluşmadığını ve yalnızca sosyal medya kanallarıyla sınırlı olmadığını söylemek mümkündür. Kişiler oyun oynamak, film izlemek, günlük gazete okumak, araştırma yapmak, tavla, okey, kâğıt oyunları gibi çeşitli kumar faaliyetlerine katılmak amaçlarıyla da interneti kullanabilmektedir. İnternet kullanım amaçlarının çok çeşitli ve birbirinden farklı olması Bilgiz ve Peker'in (2020) çalışmasında da vurgulanmaktadır İnternet kullanım amacı ve süresi, kişinin siber zorbalığa uğrama durumunu etkileyebilmektedir (Duman ve Bridge, 2019). Herhangi bir siber tehditle karş1laştınız mı $(\% 76,3)$ ve herhangi bir siber tehdit gösterdiniz mi $(\% 97,4)$ sorularına katılımcılar büyük oranda "hayır" yanıtını verseler de, burada bir nokta dikkati çekmektedir. Siber zorbalığa uğradım diyenlerin $(\% 23,7)$ oranı siber zorbalık yaptım diyenlerin $(\% 2,6)$ oranından daha fazladır. Siber zorbalığa karşı haklarınızı biliyor musunuz sorusuna katılımcıların \%63'ü, nereden yardım alacağınızı biliyor musunuz sorusuna ise \%63,6's1 "hayır" cevabını vermiştir. $\mathrm{Bu}$ durumda siber zorbalık karşısında katılımcılar hem haklarını hem de nereden yardım alacaklarını bilememektedirler. 
Siber zorbalık durumunun yaşa göre değişip değişmediği incelenmiş ve yaş grupları arasında anlamlı istatistiksel farkların olduğu görülmüştür. Buna göre hem siber zorbalığa uğrayan hem de siber zorbalık yapan kişilerin 15-24 yaş arasındaki kişiler olduğu ortaya çıkmıştır. Siber zorbalığa uğrama ile siber zorbalık gösterme arasındaki ilişkiyi incelemek için yapılan korelasyon analizi sonucunda da siber zorbalık yapma ile siber zorbalığa uğrama arasında orta düzeyde bir ilişki olduğu görülmüştür. Buna göre siber zorbalık yapan kişilerin bir gün kendilerinin de siber zorbalığa uğrayacağı bu araştırmanın sonuçlarına dayanılarak söylenebilir. Her yaştan ve her cinsiyetten kişilerin siber zorbalık durumuyla karşılaşabileceği unutulmamalıdır. Bir başka dikkati çeken sonuç ise 45-54 yaş arasındaki kişilerinde siber zorbalığa uğradıklarıdır. Daha yaşlı kişiler, daha genç bireyler tarafından siber zorbalığa maruz kalmaktadır. Bu durumda interneti daha iyi bilen, daha aktif kullanan, daha güçlü kişiler, zayıf olarak görülen, interneti kullanmada sıkıntı yaşayan daha yaşlı kişilere zorbalık yapabilmektedir. Önceki çalışmalarında sonuçları bu yöndedir (Dikmen ve Tuncer, 2017; Özmen, 2018).

Siber zorbalık durumunun cinsiyete göre farkına bakıldığında, her iki cinsiyetinde siber zorbalığa uğradığı yani hem kadınların hem erkeklerin internet ortamındaki yıkıcı psikolojik ve ruhsal baskılamaya maruz kaldı̆̆ı görülmüştür. Ancak siber zorbalık gösterme davranışlarının erkeklerde daha fazla olduğu ortaya çıkmıştır. Cinsiyete yönelik siber zorbalık durumu literatürdeki diğer çalışmaların sonuçlarıyla benzerlik taşımaktadır. Örneğin, kızların çok daha fazla siber zorbalığa uğradı̆̆ı, erkeklerinse siber zorbalık göstermede kızlara göre daha önde olduğu sıklıkla vurgulanan sonuçlardandır (Korkmaz, 2016; Erbiçer, 2019). Siber zorbalık durumunun gelirle ilişkisine bakıldığında, siber zorbalık yapanlar açısından anlamlı bir farkın olmadığı fakat siber zorbalığa uğrayanların daha çok asgari ücret ve altı gelir düzeyine sahip kişiler olduğu ortaya çıkmıştır. Literatür incelendiğinde genel itibariyle siber zorbalıkla gelir arasında bir ilişkiye rastlanmadığı görülmektedir (Çiftçi, 2010; Eroğlu, 2011; Türkoğlu, 2013; Duman ve Bridge, 2019) ancak bizim çalışmamızda siber zorbalığa uğrama ile gelir arasında anlamlı bir ilişkinin olduğu görülmüştür. Asgari ücret ve altı gelire sahip olan kişilerin hem siber zorbalık gösterdikleri hem de buna maruz kaldıkları görülmüştür. Zorbalık davranışının gelirle olan bağlantısı ileride yapılacak nitel araştırmalarda derinlemesine araştırılabilir ve daha zengin içgörüler elde edilebilir. Bu sonuç literatüre yeni bir tartışma konusu eklemektedir. 
Siber zorbalık davranışlarının internette geçirilen süre ile olan ilişkisine bakıldığında daha çok internette vakit geçirenlerin daha fazla zorba davranışlar sergilediği bulunmuştur. Buna göre internette günde 7-9 saat ile 10 saat ve üzeri vakit geçiren kişiler siber zorbalık gösterme davranışlarına daha yatkındır. Ancak siber zorbalığa uğramak için internette geçirilen sürenin daha kısa olduğu görülmüştür. Buna göre 4-6 saat ile 10 saat ve üzeri vakit geçirenler siber zorbalığa uğrayabilmektedir. İnternette geçirilen süre arttıkça siber zorbalığa uğrama ihtimali de artmaktadır. Bu araştırmanın sonuçları Hinduja ve Patchin (2008), Laird (2012), Dikmen ve Tuncer (2017) ile Duman ve Bridge (2019)'un çalışma sonuçlarıyla benzerlik göstermektedir. Siber zorbalık davranışlarının sosyal medyada geçirilen süre ile olan ilişkisine bakıldığında yine daha fazla sosyal medyada vakit geçirenlerin hem siber zorbalık gösterdiği hem de siber zorbalığa uğradıkları görülmüştür (7-9 saat arası ve 10 saat üzeri). Sosyal medyada geçirilen süre arttıkça siber zorbalığa uğrama riskinin de artacağı bu araştırmaya dayanılarak söylenebilir. Bu bulgu önceki çalışmalarla benzerlik göstermektedir (Hinduja ve Patchin, 2008; Laird, 2012; Dikmen ve Tuncer, 2017; Dinç, 2020: 36). Bu anlamda sosyal medya araçları siber zorbalığın en çok uygulandığı mecralar olarak karşımıza çıkmaktadır.

Gelecekteki çalışmalar siber zorbalığı önlemede hangi aksiyonların alınması gerektiğine dair öğretmenler, Milli Eğitim yöneticileri ve hükümet düzeyindeki yetkililer ile derinlemesine mülakatlar şeklinde yapılabilir. Çünkü siber zorbalık konusundaki geniş literatür bizlere bu davranışların sosyal medya ve internet kullanımındaki artıştan, annebaba eğitim seviyesinden ve ebeveyn ilgisinden, kişilerin bazı demografik faktörlerinden etkilendiğini söylemektedir. Ancak bu davranışların önlenmesine dair ipuçları nispeten daha azdır. Ayrıca gelecekteki çalışmalar, sosyal medya fenomenleri ile görüşülerek, ergen ve yetişkinlerin sosyal medya okur-yazarlığı bilinci kazanmasında ne gibi iş birliklerin gerçekleştirilebileceğine dair başlıklar üzerine yapılabilir. Çevrimiçi oyunların siber zorbalık davranışlarına olan katkısı da ileride yapılacak çalışmalar için ilginç konu önerilerinden biri olabilir. İnternetin yaygın kullanımı ile birlikte artan bu davranışların önlenmesinde disiplinler arası yaklaşımın benimsenmesi, Milli Eğitimden, yerel yönetimlerden ve ailelerden oluşacak danışma kurulları ile soruna köktenci çözüm önerilerinin sunulması, akademik yayınlardan istifade edilerek önceliğin hangi yaş gruplarına verileceğinin belirlenmesi, gelecekte yaşanabilecek olumsuz durumları önlemeden son derece önemlidir. Burada dikkat edilmesi gereken esas konu internet ve 
sosyal medya kullanımının yasaklanması değil bilinçli kullanımının arttırılmasıdır. Gençlere bu konuda medya okuryazarlığı eğitimi verilmeli, küçük yaşlardan itibaren internetin faydalı yönlerine odaklanmaları sağlanmalıdır (Kaygısız, 2019). 


\section{KAYNAKÇA}

Akbaba, S. ve Eroğlu, Y. (2013). İlköğretim Öğrencilerinde Siber Zorbalık ve Mağduriyetin Yordayıc1ları. Uludă̆ Üniversitesi Ĕ̆itim Fakültesi Dergisi, 29(1): 105-121.

Akça, E. B., Sayımer, İ., Salı, J. B. ve Başak, B. E. (2014). Okulda Siber Zorbalığın Nedenleri, Türleri ve Medya Okur Yazarlığı Eğitiminin Önceliği Çalışmalarındaki Yeri. Elektronik Mesleki Gelişim ve Araştırma Dergisi, 2: 1730 .

Aktepe, E. (2013). Ergenlerde Siber Zorbalık ve Siber Mağduriyet. New Symposium Journal, 51: 31-36.

Alanoğlu, M. ve Karabatak, S. (2020). Öğretmenlerin Okullarda Siber Zorbalığa Maruz Kalma Düzeylerinin Araştırılması. Mehmet Akif Ersoy Üniversitesi Ĕgitim Fakültesi Dergisi, 55: 45-70. Doi: 10.21764/maeuefd.582236

Ateş, B. ve Güler, M. (2016). Ergenlerde Siber Zorbalığın Yordayıcısı Olarak Algılanan Sosyal Yetkinlik ve Toplumsal Kaygı. Erzincan Üniversitesi Eğitim Fakültesi Dergisi, 18(1): 391-408. Doi: 10.17556/jef.01832

Aydın, M. ve Çelik, T. (2019). Velilerin Gözünden Sosyal Medyanın Ortaokul Öğrencileri Açısından Yarar ve Riskleri. Mehmet Akif Ersoy Üniversitesi Ĕ̈itim Fakültesi Dergisi, 50: 110-135. Doi: 10.21764/maeuefd.488456

Bilgiz, S. ve Peker, A. (2020). Ergenlerde kişisel ve çevresel faktörlerin siber zorbalık davranışını yordaması. Cumhuriyet International Journal of Education, 9(2), 430-447. Doi: 10.30703/cije.613212

Chang, F.C., Chiu, C.H., Lee, C.M., Chen, P.H. ve Miao, N.F. (2014). Predictors of the initiation and persistence of internet addiction among adolescents in Taiwan. Addictive Behaviors, 39(10): 1434-1440. Doi: 10.1016/j.addbeh.2014.05.010

Çiftçi, S. (2010). Dokuzuncu sınıf öğrencilerinin sanal zorbalık düzeyleri ile empatik eğilim düzeyleri arasındaki ilişki. Yayımlanmamış Yüksek Lisans Tezi. Enstitüsü Gaziosmanpaşa Üniversitesi Sosyal Bilimler Enstitüsü, Tokat.

Çivilidağ, A. ve Cooper, H. T. (2013). Ergenlerde Siber Zorba ve Öfkenin İncelenmesi Üzerine Bir Araştırma: Niğde İli Örneği. International Journal of Social Science Studies, 6(1): 497-511.

Dikmen, M. ve Tuncer, M. (2017). Akademisyenlerin Siber Zorbalığa Yönelik Algıları ve Mücadele Etme Yöntemleri. Dicle Üniversitesi Ziya Gökalp Eğitim Fakültesi Dergisi, 31: 675-686. Doi: 10.14582/DUZGEF.1806

Dinç, E. S. (2020). Sosyal Medya Ortamlarında Siber Zorbalık: Lise Öğrencilerinin Siber Zorbalık Deneyimlerinin İncelenmesi. Yeni Medya Elektronik Dergisi, 4(1): 2439. Doi: 10.17932/IAU.EJNM.25480200.2020.4/1.24-39 
Duman, N. ve Bridge, E. N. (2019). Siber Mağduriyet, OPUS Uluslararası Toplum Araştırmaları Dergisi, 10 (17): 1156-1178. Doi: 10.26466/opus.528679

Bolat, D. ve Korkmaz, Ö. (2021). Ortaokullarda Ergenlik Çağındaki Öğrencilerin Siber Zorbalık Davranışları, Sosyal Medya Bağımlılıkları ve Sosyal Medya Bozuklukları. Türkiye Sosyal Araştırmalar Dergisi, 25(1): 253-267.

Bostan, T., Bostan, A., Sarpkaya, S. ve Yabacı, A. (2020). Lise öğrencilerinin siber zorbalık düzeyleri ve siber zorbalığa karşı verdikleri tepkilerin çeşitli değişkenler açısından incelenmesi. Premium e-Journal of Social Sciences (PEJOSS), 4(9), 321-332.

Dursun, S., Gökçe, A. ve Aytaç, S. (2020). Siber Zorbalık: Üniversite Öğrencileri Üzerine Bir Araştırma. International Journal of Social Inquiry, 13(2): 465-485. Doi: $\underline{10.37093 / i j s i .837694}$

Efe, Y.S., Erdem, E. ve Vural, B. (2021). Lise Öğrencilerinde Siber Zorbalık ve İnternet Bağımlılı̆̆1, Journal of Dependence, 22(4): 465-473. Doi: 10.51982/bagimli.936930

Erbiçer, E. S. (2019). Siber zorbalık ve siber mağduriyetin sosyal uyuma ve bazı demografik değişkenlere göre incelenmesi. Pamukkale Üniversitesi Eğitim Fakültesi Dergisi, 49: 1-24. Doi: 10.9779/pauefd.559831

Erdur-Baker, Ö. ve Karşut, F. (2007). Akran Zorbalığının Yeni Yüzü: Siber Zorbalık. Eurasian Journal of Educational Research, 27: 31-42.

Eroğlu, Y. (2011). Koşullu Öz-Değer, Riskli İnternet Davranışları, İnternet Kullanım Sıklığı ve Siber Zorbalık Arasındaki İlişkinin İncelenmesi. Sakarya Üniversitesi Eğitim Bilimleri Enstitüsü, Eğitimde Psikolojik Hizmetler Bilim Dalı, Yüksek Lisans Tezi.

Eroğlu, Y. ve Peker, A. (2015). Ergenlerde Akran İlişkileri ile Siber Zorbalık Statüleri Arasındaki İlişkinin İncelenmesi. Turkish Studies, 10(11): 593-606. Doi: 10.7827/TurkishStudies.8574

Field, T. (2018). Cyberbullying: A Narrative Review. Journal of Addiction Therapy and Research, 2: 10-27. Doi: 10.29328/journal.jatr.1001007

Forssell, R. (2016). Exploring cyberbullying and face-to-face bullying in working lifePrevalence, targets and expressions. Computers in Human Behavior, 58, 454-460. Doi: $10.1016 /$ j.chb.2016.01.003

Forssell, R. C. (2018). Gender and organisational position: predicting victimisation of cyberbullying behaviour in working life. The International Journal of Human Resource Management, 1-20. Doi: 10.1080/09585192.2018.1424018

Hinduja, S. ve Patchin, J. W. (2008). Cyberbullying: An Exploratory Analysis of Factors Related to Offending and Victimization. Deviant Behavior, 29(2): 1- 29. Doi: $\underline{10.1080 / 01639620701457816}$

İğdeli, F. (2018). Üniversite Öğrencilerinin Siber Zorbalık, Siber Mağduriyet ve Siber Zorbalık Duyarlılıklarının Çeşitli Değişkenler Bağlamında İncelenmesi. Anadolu 
Üniversitesi Eğitim Bilimleri Enstitüsü, Bilgisayar ve Öğretim Teknolojileri Eğitimi Anabilim Dalı, Yüksek Lisans Tezi.

Karoğlu, T.T. ve Çıl̆ğı, M. (2020). Lise Öğrencilerinin Siber Zorbalığı ve Siber Mağduriyeti Üzerine Bir Çalışma. Sosyal Bilimler ve Eğitim Dergisi, 3(1): 344355 .

Kaygısız, E.G. (2019). Şiddetin E-Hali: Siber Zorbalık. Türkiye Insan Hakları ve Eşitlik Kurumu Akademik Dergisi, 4(5): 161-174.

Kaygısız, E.G. ve Çakır, Ç. (2020). Siber zorbalık ve siber mağduriyet ekseninde özsayg1 ve iş tatmini ilişkisi. Turkish Studies, 15(5): 2463-2479. Doi. https://dx.doi.org/10.7827/TurkishStudies.43596

Korkmaz, A. (2016). Siber Zorbalık Davranışları Sergileme ve Siber Zorbalığa Maruz Kalma Durumlarının Karşılaştırılması. TRT Akademi Dergisi, 1(2): 620-639.

Laird, S. (2016). Cyberbullying: Scourge of the Internet. http://mashable.com/2016/03/03/cyberbullying-infographic/\#_5DgxlRuBZqd (Erişim Tarihi: 10.09.2021).

Öksüzoğlu, T.Ö. (2021). Kadınlara yönelik siber zorbalık durumları ve önlem çalışmaları. European Journal of Educational and Social Sciences, 6(1): 67-75.

Özateş Gelmez, Ö.S. (2020). Ortaokul Öğrencilerinin Siber Zorbalığa İlişkin Duyarlılıklarının İncelenmesi. Gençlik Araştırmaları Dergisi, 8(Özel Sayı): 7590.

Özdemir, Ö. (2019). Cyberbullying As A Virtual Threat Among Youth. Karadeniz Uluslararası Bilimsel Dergi, 41: 80-91.

Özer, N. ve Şad, S.N. (2021). Lise Öğrencilerinde Siber Zorbalık, Siber Mağduriyet ve Okul Tükenmişliği, Milli Eğitim Dergisi, 50(229): 393-417

Özmen, Ş. Y. (2018). Dijital Şiddet, Siber Zorbalık ve Yeni Medya Okuryazarlığg Üzerine Bir Değerlendirme. Uluslararast Sosyal Araştırmalar Dergisi, 11(61): 958-966. Doi: http://dx.doi.org/10.17719/jisr.2018.2989

Peker, A. (2015). Ergenlerin Saldırganlık ve Siber Zorbalık Davranışları Arasındaki İlişkilerin İncelenmesi. EKEV Akademi Dergisi, 19(61): 323-336.

Toraman, L. ve Usta, E. (2018). Ortaokul Öğrencilerinin Dijital Yerli ve Siber Zorba Olma Durumlarının Çeşitli Değişkenler Açısından İncelenmesi. Ondokuz Mayıs Üniversitesi Eğitim Fakültesi Dergisi, 37(2): 57-77. Doi: 10.7822/omuefd.378621

Türkoğlu, S. (2013). Ergenlerin problemli internet kullanımları ile siber zorbalık eğilimleri arasındaki ilişkinin incelenmesi, Yüksek Lisans Tezi. Marmara Üniversitesi Eğitim Bilimleri Enstitüsü, İstanbul. 
Yelboğa, N. ve Koçak, O. (2018). Lise Öğrencilerini Akran Zorbalığına İten Nedenlerin Değerlendirilmesi ve Artvin Örneği. İstanbul Ticaret Üniversitesi Sosyal Bilimler Dergisi, 35: 771-802. 